\title{
Sex differences in basal hypothalamic anorectic and orexigenic gene expression and the effect of quantitative and qualitative food restriction
}

\author{
S. D. Caughey ${ }^{1 *}$, P. W. Wilson ${ }^{1}$, N. Mukhtar ${ }^{1}$, S. Brocklehurst ${ }^{2}$, A. Reid ${ }^{1}$, R. B. D’Eath ${ }^{3}$, T. Boswell ${ }^{4}$ and I. C. Dunn ${ }^{1}$
}

\begin{abstract}
Background: Research into energy balance and growth has infrequently considered genetic sex, yet there is sexual dimorphism for growth across the animal kingdom. We test the hypothesis that in the chicken, there is a sex difference in arcuate nucleus neuropeptide gene expression, since previous research indicates hypothalamic AGRP expression is correlated with growth potential and that males grow faster than females. Because growth has been heavily selected in some chicken lines, food restriction is necessary to improve reproductive performance and welfare, but this increases hunger. Dietary dilution has been proposed to ameliorate this undesirable effect. We aimed to distinguish the effects of gut fullness from nutritional feedback on hypothalamic gene expression and its interaction with sex.
\end{abstract}

Methods: Twelve-week-old male and female fast-growing chickens were either released from restriction and fed ad libitum or a restricted diet plus $15 \% \mathrm{~W} / \mathrm{W}$ ispaghula husk, a non-nutritive bulking agent, for 2 days. A control group remained on quantitative restriction. Hypothalamic arcuate nucleus neuropeptides were measured using real-time PCR. To confirm observed sex differences, the experiment was repeated using only ad libitum and restricted fed fast-growing chickens and in a genetically distinct breed of ad libitum fed male and female chickens. Linear mixed models (Genstat 18) were used for statistical analysis with transformation where appropriate.

Results: There were pronounced sex differences: expression of the orexigenic genes AGRP $(P<0.001)$ and NPY $(P<0.002)$ was higher in males of the fast-growing strain. In genetically distinct chickens, males had higher AGRP mRNA $(P=0.002)$ expression than females, suggesting sex difference was not restricted to a fast-growing strain. AGRP $(P<0.001)$ expression was significantly decreased in ad libitum fed birds but was high and indistinguishable between birds on a quantitative versus qualitative restricted diet. Inversely, gene expression of the anorectic genes POMC and CART was significantly higher in ad libitum fed birds but no consistent sex differences were observed.

Conclusion: Expression of orexigenic peptides in the avian hypothalamus are significantly different between sexes. This could be useful starting point of investigating further if AGRP is an indicator of growth potential. Results also demonstrate that gut fill alone does not reduce orexigenic gene expression.

Keywords: Sex, Psyllium, AGRP, POMC, Satiety, Growth, Body weight

\footnotetext{
* Correspondence: sarah.caughey@roslin.ed.ac.uk

${ }^{1}$ The Roslin Institute and Royal (Dick) School of Veterinary Studies, University

of Edinburgh, Easter Bush, Midlothian, Edinburgh EH25 9RG, Scotland, UK

Full list of author information is available at the end of the article
}

(c) The Author(s). 2018 Open Access This article is distributed under the terms of the Creative Commons Attribution 4.0 International License (http://creativecommons.org/licenses/by/4.0/) which permits unrestricted use, distribution, and reproduction in any medium, provided you give appropriate credit to the original author(s) and the source, provide a link to the Creative Commons license, and indicate if changes were made. The Creative Commons Public Domain Dedication waiver (http://creativecommons.org/publicdomain/zero/1.0/) applies to the data made available in this article, unless otherwise stated. 


\section{Background}

Sexual dimorphism is all around us; differences in plumage, pelage or ornamentation are observed across the animal kingdom with many species also displaying difference in body size and weight [1]. Most commonly, males are larger than females, but in some cases, the female is the largest sex with many examples in predatory birds, but also cases in mammals such as the blue whale and spotted hyena [26]. Research into the role of gene products such as agoutirelated protein (AGRP) and pro-opiomelanocortin (POMC) in the control of energy balance in birds, or in mammals, has not paid particular attention to the sex of the animals studied [7]. Given the large difference in growth between males and females of many species, this is surprising, although as in our own studies on food intake and metabolism, a focus on one sex is sometimes made for industrial relevance [8-10]. In many galliforms, as in most mammals, the male grows larger and faster than the female; indeed, the domestic chicken displays one of the clearest sexual dimorphisms in body weight, with males around 20\% heavier and with a clear difference in growth rate long before sexual or somatic maturity $[11,12]$. This dimorphism for body weight holds true across the spectrum of chicken lines: in fast-growing meat-type chickens, in crosses between $\mathrm{O}$ Shamo game bird and white leghorns and in egg-laying strains $[11,13,14]$. Selection for growth appears not to have in any way altered the sex difference in body weight, and the genetic correlation between male and female sibs of meat-type chickens is extremely high, with no evidence that the sex difference between them has a heritable component [11]. In other words, the differences in body weight are related entirely to the sex chromosomes inherited (in birds male ZZ, female ZW), and not to any interaction with the rest of the genome. From a practical point of view, selecting either sex for improved growth rate would be equally effective.

The central regulation of energy balance is conserved between birds and mammals, with the arcuate nucleus of the hypothalamus containing one population of neurons producing both AGRP and neuropeptide Y (NPY) with another synthesising $\alpha$-melanocyte-stimulating hormone $(\alpha \mathrm{MSH})$ and other peptides from the POMC gene, and co-expressing cocaine- and amphetamine-regulated transcript (CART) mRNA [15-17]. The balance of POMC and AGRP is critical for controlling food intake; POMC neurons produce $\alpha \mathrm{MSH}$ which acts on melanocortin 4 receptors (MC4Rs) to inhibit food intake, and contrastingly, AGRP acts as an antagonist on the same receptors to increase food intake and energy storage [18, 19]. Intracerebroventricular (ICV) injection of AGRP attenuated the anorectic effect of $\alpha \mathrm{MSH}$ on food intake in both layer and broiler chicks; however, only in layer chicks did AGRP increase food intake under ad libitum feeding conditions suggesting the orexigenic effects of AGRP are different between layers and broilers [19]. We have previously shown that the expression of AGRP mRNA in the arcuate nucleus is increased many-fold in broiler breeder chickens under feed restriction compared to those fed ad libitum, whereas the anorectic peptide POMC mRNA was relatively unchanged [10]. In a line of chickens segregating at the cholecystokinin A receptor (CCKAR) locus, the autosomal genomic locus with the largest effect on growth and body weight, hypothalamic $A G R P$ expression was higher in the animals carrying the high growth allele which had lower CCKAR mRNA and protein expression [8]. Furthermore, hypothalamic AGRP expression in growing chickens was shown to be responsive to both short- and long-term food availability [10]. This indicated that the AGRP neurones have a potentially important role in the control of feeding behaviour in birds because the level of $A G R P$ mRNA represented not only the immediate satiety state of the bird but also how far the bird was from its body weight if it had not been food restricted [10]. In other words, hypothalamic AGRP expression in a number of different situations appears consistent in giving an indication of growth potential as much as short-term motivation to eat. Therefore, as our primary aim, we wanted to determine if genetic sex would be reflected in differences in AGRP expression.

There is currently a great deal of interest in the control of food intake in the context of overconsumption and obesity in humans whilst in domesticated animals it is particularly important for the efficient growth and production of meat. Chicken meat and eggs provide at least a third of the world's animal protein [20]. Genetic selection in meattype chickens has led to threefold increases in growth and feed efficiency [21]. Capitalising on this genetic potential has come with some adverse consequences. The parents of these meat-type chickens, known as broiler breeders, become overweight if allowed to feed ad libitum during rearing and to a lesser extent through the reproductive period, leading to poor welfare, decreased productivity and increased morbidity and mortality of up to 31\% [2226]. Food restriction is used successfully in the poultry industry to control these issues, with peak restriction around $25 \%$ of the ad libitum intake at 7-14 weeks of age. The birds show high levels of food motivation, with broiler breeders willing to experience an aversive stimulus to perform exploratory and foraging behaviour even when there was no food reward [27]. These conflicting welfare issues became known as the 'broiler breeder paradox' [24, 28, 29]. Understanding how growth is controlled and how differences in growth are genetically determined are, therefore, of key interest. Furthermore, investigating how the activity of anorectic and orexigenic neurons is related to growth is of potential importance in allowing it to be manipulated. One potential solution to the welfare problem of food-restricted broiler breeders experiencing prolonged 
hunger is to move from quantitative restriction to qualitative restriction by using dietary diluents to effectively lengthen the feeding period, change behaviour and apparently increase satiation whilst still restricting body weight [30-34]. The question remains, however, as to whether these approaches increase satiation indicators centrally. A second objective of this study was therefore to investigate whether the short-term inclusion of a fibrous bulking agent, the arabinoxylan fibre source Psyllium, also known as ispaghula husk, in the diet alters the gene expression of arcuate nucleus neuropeptides in a release from restriction model [10]. Psyllium in humans and laboratory rodents has been shown to have satiating effects, attributed to the effects of slowing down the absorption of nutrients by increasing bulk through its action of absorbing of large amounts of water. Psyllium is also not digestible or fully fermentable due to its complex polysaccharide structure, but it possibly increases the production of short-chain fatty acids in the distal gastrointestinal tract which may have satiating effects [35-37].

This study therefore had two main aims: firstly, to test the hypothesis that there is a sex difference in gene expression of neuropeptides controlling food intake in the hypothalamic feeding circuitry. Secondly, to test the hypothesis that qualitative food restriction induces a different pattern of gene expression in the arcuate nucleus compared to quantitative restriction; in other words, to distinguish the effects of gut fullness from nutritional signal feedback on the expression of central orexigenic and anorexigenic signals. These two aims were examined together to determine if there was any interaction between sex and dietary restriction, whether qualitative or quantitative, on hypothalamic gene expression.

\section{Methods}

\section{Animal experiments}

Sex and diet effect: To test the effect of sex and release from quantitative food restriction to qualitative restriction on basal hypothalamic neuropeptide gene expression

Un-sexed mixed female and male Ross 308 broiler breeders were group housed in three batches (hatches, $n=24$ ) from hatch until 1 week prior to the experiment. Lighting, nutritional composition of the food and dietary restriction from day-old to 11 weeks of age was implemented in accordance with the breeders' 2016 management manual (http://eu. aviagen.com/assets/Tech_Center/Ross_PS//308SF-PS-EU-P O-EN-16.pdf) and similar to detailed previously [10]. Our experiment was conducted when birds were 12 weeks of age which is within the peak period of food restriction for broiler breeders (7-14 weeks of age), a point where growth is almost at maximum and well before sexual maturity which typically occurs at around 20 weeks onward [38].

One week prior to the experiment, birds were weighed, ranked and randomised according to body weight and then assigned an individual cage and one of three treatment groups. For each of three replicate batches, six birds $(n=2$ per treatment group) were transferred to their allocated individual cages in a new room on 4 successive days (different room for each day) and allowed to acclimatise for 6 days with continued commercial feed restriction. Birds were either then released from restriction and allowed to feed ad libitum (AL), fed the commercial restricted diet ration plus $15 \% w / w$ ispaghula husk ( $\mathrm{IH})$ or maintained on the commercial restricted diet ration (FR). The diets were fed for 2 . 5 days, and the birds were then killed with an intravenous injection of sodium pentobarbitol. In each batch, dissections ( $n=6$ per day) were performed when the birds were on average 11 weeks old over 4 days with equal numbers from the different treatment groups each day. All dissections were performed after 14.00 ( $7 \mathrm{~h}$ after lights on) with one bird from each triplet of treatment being sampled sequentially but randomly to minimise the effect of sample time. Basal hypothalamic brain tissue (40-100 mg) was dissected as previously described [39] and snap frozen on dry ice before being stored at $-80{ }^{\circ} \mathrm{C}$ until processed to extract RNA. The group size for each treatment was 24. Sex was determined at dissection with broadly equal number of each sex in each treatment. Ten birds (of 72) were lost to the study (2 AL, 3 FR and $3 \mathrm{IH}$ ) due to early illness.

\section{Sex effect repeat: To repeat the experiment on the effect of sex and release from quantitative food restriction on the expression of anorectic and orexigenic peptide genes in the basal hypothalamus}

Experiment section "Sex and diet" was repeated using the same line of chickens with the omission of the IH group to ensure the sex difference results observed in section "Sex and diet" were repeatable. Two replicate batches were used with dissections of eight birds $(n=4$ per treatment group) performed when the birds were on average 12 weeks old over 2 days in each batch. The group size for each treatment was 16, designed with equal numbers of males and females per treatment based on genetic sexing [40]. One bird was lost to the study (AL female) and one AL bird thought initially to be female was male.

\section{Genetically distinct line: To test the effect of sex on basal hypothalamic anorectic and orexigenic gene expression in a genetically distinct line of chickens}

Female $(n=15)$ and male $(n=14)$ birds from the 20th generation of a broiler layer hybrid line [9] were reared in group housing under 14L:10D lighting and $26^{\circ} \mathrm{C}$ temperature (ambient) and allowed to feed ad libitum on a standard grower diet until they were humanely killed at 10 weeks of age. There were five pens of bird used in the study which was confounded with hatch. All birds were heterozygotic for the previously described CCKAR locus alleles [9]. This line whilst not requiring feed restriction to maintain 
reproductive performance in adulthood does benefit from a moderate restriction that increases the production of viable eggs. Chickens were culled with an overdose of sodium pentobarbital and basal hypothalamus samples dissected as described for experiment section "Sex and diet effect."

\section{Ethics statement}

All animal experiments were performed under UK Home Office Project Licence 70/7909, and birds were humanely killed as specified in Schedule 1 of the UK Animals (Scientific Procedures) Act 1986.

\section{RNA extraction and reverse transcription}

RNA was extracted from up to $100 \mathrm{mg}$ of tissue with TRIreagent (Ambion, Life Technologies, UK) and Lysing Matrix D tubes using a FastPrep Instrument FP120 (Thermo Electron Corporation, UK) and then purified according to manufacturers' instructions using a Zymo Direct-zol ${ }^{\mathrm{m}}$ RNA mini-prep kit (Cambridge BioSciences, UK). RNA concentration was read on a NanoDrop Spectrophotometer ND1000 (LabTech International, UK). RNA $(1 \mu \mathrm{g})$ was reverse transcribed using a high capacity cDNA reverse transcription kit (Applied Biosystems; Life Technologies, UK) following the manufacturer's protocol before being diluted $5.5 \times$ and stored at $-20^{\circ} \mathrm{C}$.

\section{Real-time polymerase chain reaction (PCR) assays}

Primers and assays were as described previously [10].

\section{Statistical analysis}

All graphs and the table show means \pm standard errors of means (SEMs) on the raw data scale, apart from expression measures that were standardised by dividing by the housekeeping gene. For experiment section "Genetically distinct line," expression measures (log transformed) were analysed using an unbalanced ANOVA blocking for pen (identical to cull date) to investigate the effect of sex. Statistical analysis for experiment sections "Sex and diet effect" and Sex effect repeat were performed using linear mixed models (LMM) fitted to bird and organ weights (all log transformed except pituitary), crop content weight, feed intake (AL birds only) and expression measures (log transformed). In LMMs, random effects were included for batch (identical to the lab day for expression measures), the 12 (4 per batch) different days on which the birds were dissected (identical to spatial block), and individual birds (the residual). Body weight at post mortem was also investigated in the model, but this had little or no impact on differences between sexes in gene expression so is not reported here. Fixed effects were included for bird age (experiment section "Sex and diet effect" only, fitted as a four-level factor), diet treatment group (AL, FR, IH (experimental section "Sex and diet effect" only)), sex and the interaction between sex and treatment group. For experiment section "Sex and diet effect" because some of these are partially confounded, sequential tests were obtained testing these factors in four orders: age before and after treatment and sex, and treatment before and after sex. LMMs were fitted to all data and to data omitting outliers (as defined by the linear mixed model residuals) to confirm that results for all data reported here are not just attributable to the outliers. Post hoc tests were carried out by including contrasts in the fixed effects. $P$ values reported here are the most conservative when alternative models were fitted. $P$ values are based on approximate $F$ tests when available but otherwise are based on Wald tests. Genstat (Genstat, 16th-18th editions, Lawes Agricultural Trust, VSN International Ltd.) was used for all statistical analyses.

\section{Results}

Effect of sex and diet on basal hypothalamic neuropeptide gene expression plus physiological parameters

\section{Food intake and body and organ weight}

Restricted birds were fed $46 \mathrm{~g} /$ day which equates to approximately $25 \%$ of the food intake of the average ad libitum intake (181 g/day) at 12 weeks of age, as previously observed [10]. Birds on the IH diet were fed the restricted diet containing $15 \% \mathrm{w} / \mathrm{w}$ ispaghula husk $(52.9 \mathrm{~g} /$ day in total).

There was no difference in the food consumed in the days after release from restriction between males and females in the AL group $(P=0.792)$ in experiment section "Sex and diet effect". Similarly, there was no significant difference in body weight between males and females overall $(P=0.787)$. In experiment section "Sex effect repeat" again no differences were observed in the food intake between males $(186.33 \pm 7.17 \mathrm{~g})$ and females (188.0 $\pm 8.63 \mathrm{~g})$ in the AL group after release from restriction $(P=0.885)$ and no significant difference in body weight between sexes overall $(P=0.801)$ nor was there an interaction with treatment was observed $(P=0.930$; AL female $1795.5 \pm 87.7 \mathrm{~g}$, AL male $1785.3 \pm 38.8 \mathrm{~g}$, FR female $1515.1 \pm 58.9 \mathrm{~g}$, FR male $1495.0 \pm 41.0 \mathrm{~g}$ ).

As expected, average body weight varied with treatment group $\left(P<0.001, F_{2,46}=127.14\right)$ with the AL group (1550. $9 \pm 28.1 \mathrm{~g})$ average weight significantly higher $(P<0.001)$ than that for the FR $(1229.0 \pm 24.3 \mathrm{~g})$ and IH $(1225.9 \pm 24$. 5 g) groups $\left(F_{1,46}=191.14,187.30\right.$, respectively). There was no significant difference in the body weights between the FR and IH groups $(P=0.940)$. Average crop content weight varied with treatment $\left(P<0.001, F_{2,46}=60.31\right)$ and was significantly higher in the IH fed group $(56.14 \pm 6$. $38 \mathrm{~g})$ compared with the FR group $(9.68 \pm 2.43 \mathrm{~g}, P<0$. 001, $\left.F_{1,46}=48.38\right)$ but lower in the IH group than the AL group $\left(83.02 \pm 4.59 \mathrm{~g}, P<0.001, F_{1,46}=15.79\right)$. It was noted that whilst the restricted birds ate their ration in less than an hour, birds fed the restricted diet 
supplemented with $\mathrm{IH}$ took the entire daytime period of $14 \mathrm{~h}$ to finish the ration.

There were highly significant $\left(P<0.001, F_{2,46}=87.68\right.$ pancreas, 75.64 liver, 47.20 gizzard, $F_{2,47}=47.78$ proventriculus, $F_{2,42}=8.82$ empty gall bladder) differences in organ weights (Table 1) between treatment groups in experiment section "Sex and diet effect" with the AL group having, on average, a significantly larger liver $(P<0$. 001, $\left.F_{1,46}=80.37,137.19\right)$, gizzard $\left(P<0.001, F_{1,45}=23.88\right.$, $\left.F_{1,46}=94.39\right)$, proventriculus $\left(P<0.001, F_{1,46}=56.78, F_{1,47}\right.$ $=83.34)$, empty gall bladder $\left(P=0.012, F_{1,52}=6.78, P<0\right.$. 001, $\left.F_{1,52}=17.19\right)$ and pancreas $\left(P<0.001, F_{1,45}=148.06\right.$, $\left.F_{1,46}=110.11\right)$ than the FR and IH groups. Interestingly, the FR group had significantly larger gizzards $(P<0.001$, $\left.F_{1,46}=21.93\right)$ and livers $\left(P=0.009, F_{1,46}=7.38\right)$ than the IH group. In relation to sex, only the liver was significantly larger on average in the females compared to the males $(P$ $\left.=0.015, F_{1,51}=6.30\right)$. There were no statistically significant differences in the weights of other organs between sexes or significant interactions between treatment and sex.

\section{Effect of release from restriction to an ad libitum diet or diet containing a non-nutritious bulking agent on basal hypothalamic anorectic and orexigenic gene expression}

In experiment section "Sex and diet effect" there was a highly significant $(P<0.001)$ difference between treatment groups in average expression of $A G R P, N P Y, P O M C$ and $\operatorname{CART}\left(F_{2,51}=50.45,44.88,12.11,9.86\right.$, respectively $)$ in the basal hypothalamus of birds (Fig. 1). Expression of AGRP and NPY mRNA in the basal hypothalamus of birds released from restriction and allowed to feed AL was significantly decreased $(P<0.001)$ compared with FR birds in experiment sections "Sex and diet" (Fig. 1A, B), (AGRP $F_{1,51}=70.43$, NPY $\left.F_{1,51}=50.54\right)$ and "Sex effect repeat" (Fig. 2A, B, AGRP $F_{1,25}=27.98, N P Y F_{1,25}=21.67$ ). However, in the basal hypothalamus of birds fed the IH diet expression of $A G R P\left(P<0.001\right.$ vs $\left.A L, F_{1,51}=81.69\right)$ and $N P Y\left(P<0.001\right.$ vs AL, $\left.F_{1,51}=81.34\right)$ mRNA was high and indistinguishable from that for FR birds (Fig. 1A, B). In experiment section "Sex and diet effect" an inverse pattern was observed for the anorectic genes, POMC and CART, with significantly higher expression seen in the AL birds compared to the FR $\left(P O M C, P<0.001, F_{1,51}=23.27\right.$; CART, $\left.P<0.001, F_{1,51}=17.61\right)$ and $\mathrm{IH}(P O M C, P=0.002$, $\left.F_{1,51}=11.09 ; C A R T, P=0.001, F_{1,51}=11.80\right)$ birds (Fig. $1 C$, D) and indistinguishable between IH and FR birds. In experiment section "Sex effect repeat" there was no significant effect of treatment groups on POMC $(P=0.216)$ and CART $(P=0.625)$ expression (Fig. $2 \mathrm{C}, \mathrm{D})$.

\section{Sex differences in basal hypothalamic anorectic and orexigenic gene expression following release from restriction}

A number of pronounced sex differences in gene expression in the basal hypothalamus were observed. Across the whole of experiment section "Sex and diet effect" the expression of $A G R P\left(P<0.001, F_{1,51}=34.99\right)$ and $N P Y(P=$ $\left.0.002, F_{1,51}=11.13\right)$ mRNA was significantly higher in males compared with females (Fig. 1A, B). For AGRP and $N P Y$ mRNA, the sex difference in expression was larger within the restricted and $\mathrm{IH}$ re-fed groups than the AL group (Fig. 1A, B) although it should be noted that the

Table 1 Whole organ weights (mean \pm SEM) for broiler breeders after 2.5 days of a different feeding regime. Average organ weights for the ad libitum (AL; $n=21$ ) fed group compared with the food restricted $(F R ; n=20)$ and the food restricted plus $15 \%$ ispaghula husk $(\mathrm{IH} ; n=21)$ groups. $P$ values are from LMMs with different labels $(a, b, c)$ indicating differences between means from post hoc tests for the main treatment group effect

\begin{tabular}{|c|c|c|c|c|c|}
\hline $\begin{array}{l}\text { Average } \\
\text { Weight }\end{array}$ & & Ad Libitum (AL) & Restricted (FR) & $\begin{array}{l}\text { Restricted } \\
\text { plus } 15 \% \\
\text { Ispaghula } \\
\text { Husk (IH) }\end{array}$ & \\
\hline Proventriculus (g) & $\begin{array}{l}\text { Male } \\
\text { Female }\end{array}$ & $\begin{array}{l}6.26 \pm 0.19 \\
6.26 \pm 0.31\end{array}$ & $\begin{array}{l}4.83 \pm 0.22 \\
4.22 \pm 0.19\end{array}$ & $\begin{array}{l}4.46 \pm 0.17 \\
3.87 \pm 0.20\end{array}$ & \\
\hline Gizzard (g) & $\begin{array}{l}\text { Male } \\
\text { Female }\end{array}$ & $\begin{array}{l}51.05 \pm 2.02 \\
47.12 \pm 1.53\end{array}$ & $\begin{array}{l}39.66 \pm 2.27 \\
39.79 \pm 1.45\end{array}$ & $\begin{array}{l}35.52 \pm 2.60 \\
29.54 \pm 1.10\end{array}$ & \\
\hline Pancreas (g) & $\begin{array}{l}\text { Male } \\
\text { Female }\end{array}$ & $\begin{array}{l}4.55 \pm 0.25 \\
4.27 \pm 0.18\end{array}$ & $\begin{array}{l}2.78 \pm 0.07 \\
2.75 \pm 0.13\end{array}$ & $\begin{array}{l}2.88 \pm 0.11 \\
3.05 \pm 0.10\end{array}$ & \\
\hline $\begin{array}{l}\text { Liver }(\mathrm{g}) \\
\text { Sex } P=0.015\end{array}$ & $\begin{array}{l}\text { Male } \\
\text { Female }\end{array}$ & $\begin{array}{l}60.60 \pm 3.33 \\
61.01 \pm 3.43\end{array}$ & $\begin{array}{l}24.80 \pm 2.83 \\
33.91 \pm 2.71\end{array}$ & $\begin{array}{l}19.15 \pm 0.66 \\
21.97 \pm 1.03\end{array}$ & \\
\hline Gall Bladder (g) & $\begin{array}{l}\text { Male } \\
\text { Female }\end{array}$ & $\begin{array}{l}0.208 \pm 0.020 \\
0.213 \pm 0.015\end{array}$ & $\begin{array}{l}0.147 \pm 0.006 \\
0.165 \pm 0.017\end{array}$ & $\begin{array}{l}0.165 \pm 0.029 \\
0.118 \pm 0.017\end{array}$ & \\
\hline Pituitary (mg) & $\begin{array}{l}\text { Male } \\
\text { Female }\end{array}$ & $\begin{array}{l}4.67 \pm 0.30 \\
4.34 \pm 0.23\end{array}$ & $\begin{array}{l}4.66 \pm 0.43 \\
3.85 \pm 0.21\end{array}$ & $\begin{array}{l}4.09 \pm 0.30 \\
3.99 \pm 0.19\end{array}$ & \\
\hline
\end{tabular}



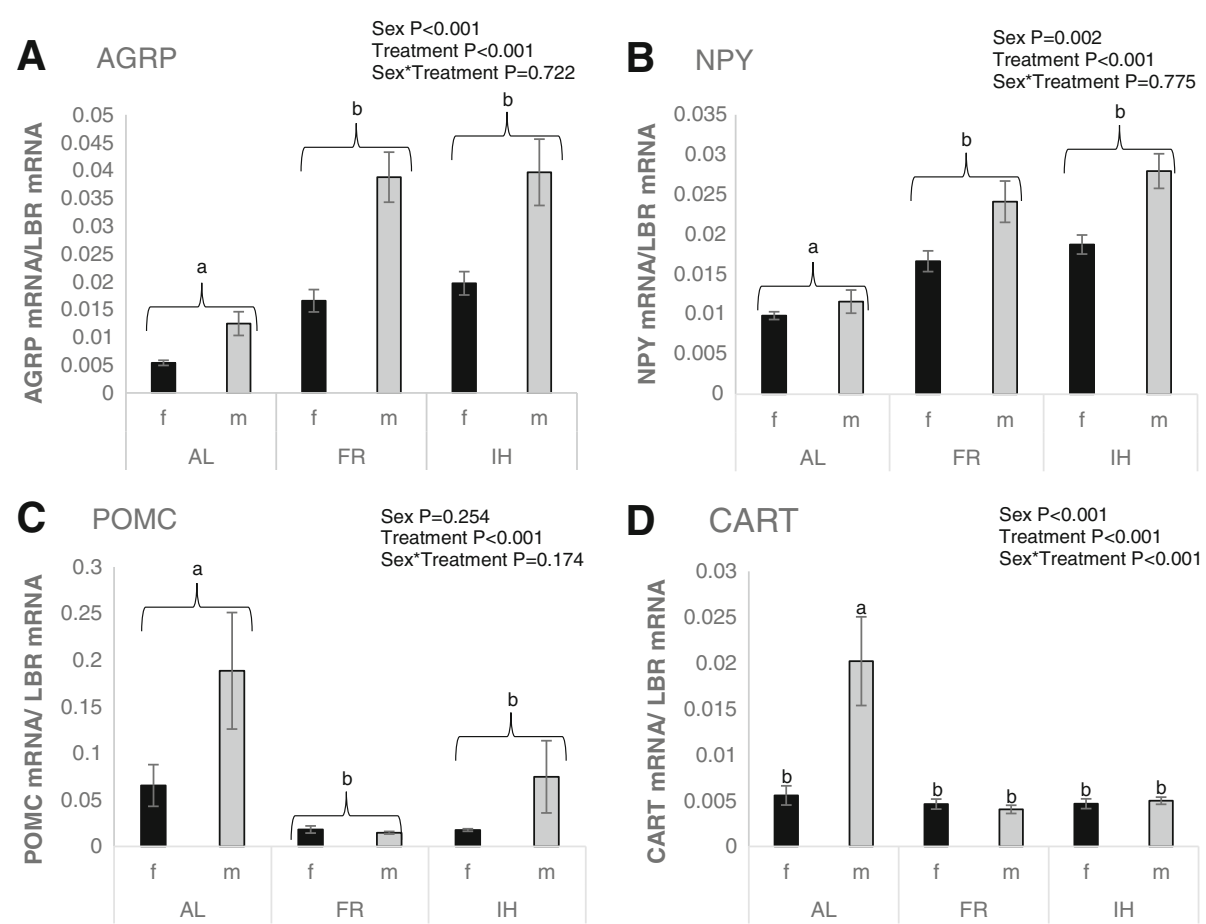

Fig. 1 Gene expression (mean $\pm S E M$ ) in the basal hypothalamus of male $(\mathrm{m})$ and female $(f)$ broiler breeders following different diets in experiment section "Sex and diet effect" Orexigenic (AGRP (A) and NPY (B)) and anorectic (POMC (C) and CART (D)) gene expression in birds fed ad libitum (AL; $n=$ 19), feed restricted (FR; $n=20)$ and birds re-fed with ispaghula husk $(I H ; n=21)$. $P$ values are from LMMs with different labels $(a$, b) indicating statistically significant $(P<0.05)$ differences between means for the treatment group effect and for the sex by treatment group interaction

interaction between sex and treatment was not significant for $\operatorname{AGRP}(P=0.722)$ or NPY $(P=0.775)$.

For anorectic genes in the basal hypothalamus, the interaction between sex and treatment was highly significant $\left(P<0.001, F_{2,51}=8.44\right)$ for $C A R T$ mRNA expression which was significantly higher in the AL male group than in all other treatment by sex groups $(P<0$. $001, F_{1,51}=22.71-32.91$; Fig. $\left.1 \mathrm{~A}\right)$. There was no statistically significant effect of sex $(P=0.254)$ or sex by treatment $(P=0.174)$ on $P O M C$ mRNA expression in the basal hypothalamus.

The sex difference in expression of orexigenic genes in the basal hypothalamus was repeatable in experiment section "Sex effect repeat" (Fig. 2). In this experiment, $\operatorname{AGRP}\left(P<0.001, F_{1,25}=19.32\right)$ and NPY $\left(P=0.003, F_{1,25}\right.$ $=10.71)$ mRNA expression was significantly higher in males compared to females (Fig. 2A, B). However, unlike in experiment section "Sex and diet effect" differences were not observed in the basal hypothalamic expression of anorectic genes between sexes (POMC $P=0.181$, $C A R T P=0.532)$. There were no significant sex by treatment interactions observed in $A G R P$ (Fig. $2 \mathrm{~A}, P=0.188$ ), NPY (Fig. 2B, $P=0.334$ ), $P O M C$ (Fig. 2C, $P=0.559$ ), or CART (Fig. 2D, $P=0.554$ ) mRNA expression in the repeat experiment.
To test the effect of sex in basal hypothalamic anorectic and orexigenic gene expression in a genetically distinct chicken line

In view of the dramatic sex differences observed in the broiler breeders, expression of arcuate nucleus genes were compared between males and females of an ad libitum fed advanced (20th generation) broiler layer hybrid line (AIL). Expression of AGRP mRNA was significantly higher in males compared with females $\left(P=0.002, F_{1,23}\right.$ $=12.90)$ but $N P Y$ expression did not differ $(P=0.425$; Fig. 3). For anorectic peptides, there was no difference in the mRNA expression of CART $(P=0.200)$ or $P O M C$ $(P=0.351)$ between sexes.

\section{Discussion}

The observation of the dramatic differences in arcuate nucleus neuropeptide expression between sexes is novel and was initially surprising to us. This has not, as far as we know, been previously investigated or observed in birds and little researched even in mammals [41-43]. In our experiments, both $A G R P$ and NPY expression were significantly higher in males than females. The sex differences in orexigenic peptide expression were repeatable and, for $A G R P$, also observed to be higher in males of a genetically distinct line of chickens. The observation 

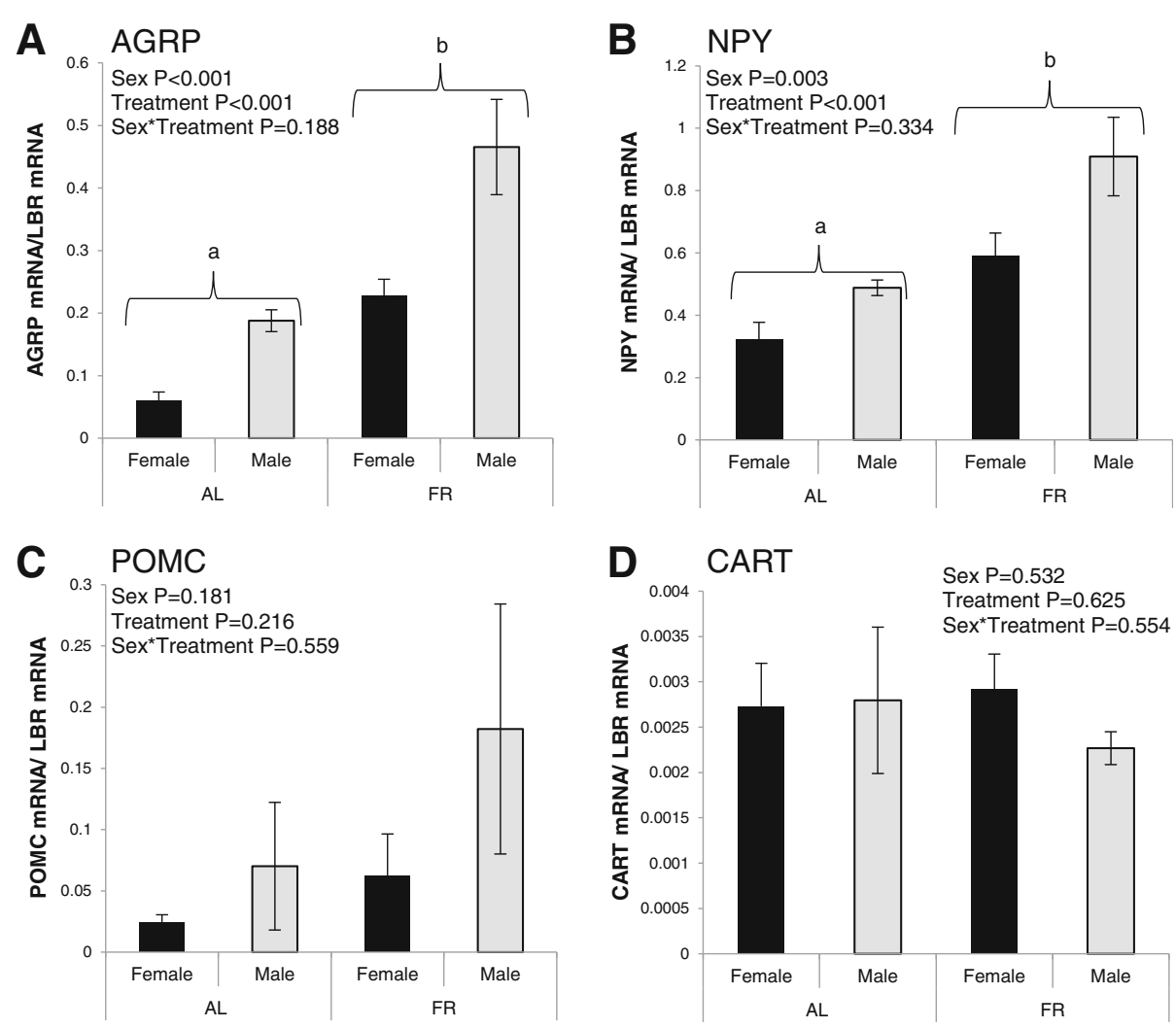

Fig. 2 Anorectic and orexigenic gene expression (mean \pm SEM) in the basal hypothalamus of male and female broiler breeders following release from commercial restriction in experiment section "Sex effect repeat" Expression of mRNA for AGRP (A), NPY (B), POMC (C) and CART (D) in the ad libitum (AL; $n=16)$ and commercial food-restricted (FR; $n=16)$ fed groups. $P$ values are from LMMs with different labels $(a$, b) indicating statistically significant $(P<0.05)$ differences between means for the treatment group effect

of no difference in NPY gene expression in the genetically distinct line of chickens may be explained by the fact they were fed ad libitum for the whole experiment. Alternatively, because NPY is relatively ubiquitous in the brain and serves other functions in contrast to AGRP, which is confined to one group of neurons, the effect of sex on the NPY mRNA in the arcuate nucleus neurones may have been diluted.

These results support existing evidence that AGRP expression relates closely to the growth potential of the bird, as much as to its nutritional state. Our previous studies found that AGRP expression levels were significantly higher in birds released from restriction for 2 weeks compared with birds released for 6 weeks prior to cull, and those having been released longest had greater body mass [10]. Thus, AGRP mRNA expression was highest in birds furthest from their growth potential. In the present study, $A G R P$ mRNA levels were higher in males who are known to grow faster and are larger than females and therefore would be furthest from their ideal body weight [11, 12]. Experiment sections "Sex and diet effect" and "Sex repeat effect" were performed with birds under restriction so no difference was observed in growth between males and females; however, in a subsequent generation of the genetically distinct line (used in experiment section "Genetically distinct line"), we have observed significant differences in the growth and weight between males and females on ad libitum feeding (see Additional file 1 Figure S1). Further evidence in the literature associating the level of $A G R P$ expression with growth potential is the observation that in chickens segregating at the CCKAR locus, which is responsible for a $19 \%$ difference in body weight by 12 weeks of age, the birds homozygous for the high growth CCKAR allele had higher $A G R P$ expression than those carrying the low growth CCKAR allele [9]. Thus, AGRP mRNA expression was higher in birds that grow larger compared to those with the low growth genotype.

One of the actions of AGRP is to increase food intake; however, there was no difference in the present study in the daily food intake between males and females when released from restriction. This may be because of the very shortterm period of the release from restriction. Equally, this study was on broiler breeders and it has been previously observed that an ICV injection of AGRP did not stimulate food intake in broiler chicks under ad libitum feeding 
A

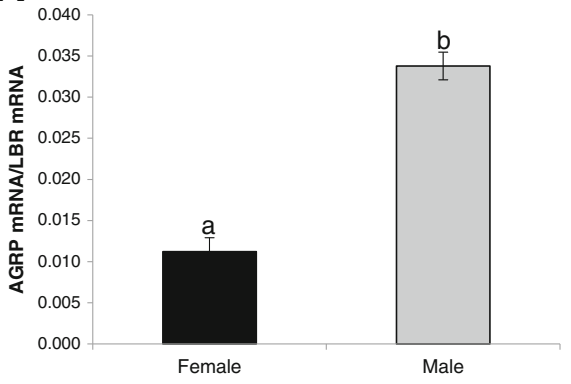

C

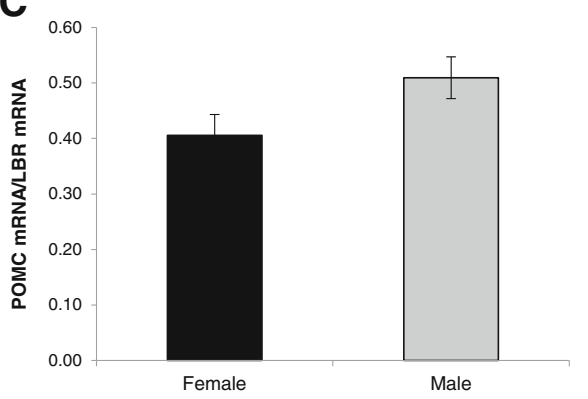

B

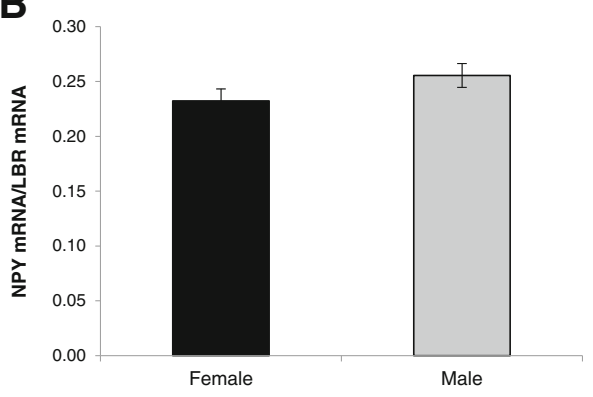

D

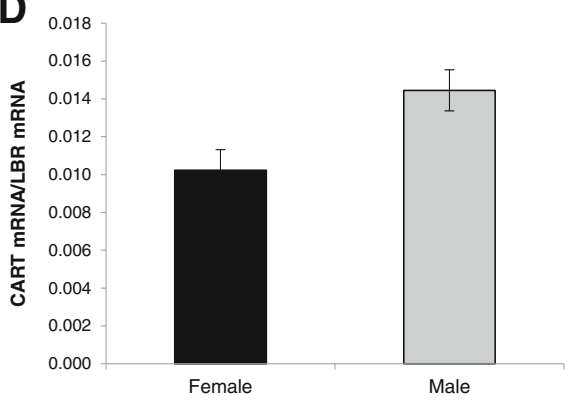

Fig. 3 Anorectic and orexigenic gene expression (mean \pm SEM) in the basal hypothalamus of male $(n=14)$ and female $(n=15)$ broiler layer hybrids (AlL) on an ad libitum diet. Expression of mRNA for AGRP (A), NPY (B), POMC (C) and CART (D). P values are from unbalanced ANOVA with different labels $(a, b)$ indicating statistically significant $(P<0.05)$ differences between means for the effect of sex

conditions whereas it did in layers [19]. The authors in that paper suggested the orexigenic effects of AGRP therefore may be different between the two breeds [19]. This is in agreement with the present study, where we did not observe higher food intake in males despite their higher AGRP expression compared with females when allowed to feed ad libitum. This raises the possibility that the actions of AGRP on food intake (in broilers at least) might be separate to its effects on growth potential, thus highlighting a key area of interest and investigation in the interaction of AGRP with the central melanocortin system and its impact upon energy balance and growth. Mouse models of obesity already suggest an involvement of AGRP in growth regulation through interaction with the melanocortin system especially the MC4R. Overexpression of AGRP in the mouse results in obesity and targeted inactivation of the MC4R causes obesity with features similar to the agouti obesity syndrome $[44,45]$. More pronounced effects of the melanocortin system on growth have been observed in teleost fish, with the sexual dimorphic difference in growth in zebrafish reversed by overexpression of the agouti-signalling protein, a melanocortin receptor antagonist [43]. In this species, targeted prevention of the translation of AGRP mRNA resulted in decreased larval growth, an effect mediated by the MC4R because MC4R knockout teleosts were resistant to the growth-supressing effects of AGRP [46]. Furthermore, recently, it has been shown chicken MC4Rs are equipotently activated by $\alpha \mathrm{MSH}$ and adrenocorticotrophic hormone $(\mathrm{ACTH})$ and this is heightened by the presence of melanocortin-2 receptor accessory protein 2 (MRAP2) whilst AGRP acts as an inverse agonist and antagonist on both MC4Rs and MC3Rs [47]. This along with the coexpression of MC4R, MC3R, AGRP, POMC and MRAP2 mRNAs in the chicken hypothalamus indicates they may be important in the control of energy balance in the chicken with similar mechanisms of action as observed in mammals and teleosts [47]. The evolutionary conserved actions of AGRP and the melanocortin system on energy balance across vertebrates leads us to hypothesise that AGRP neurons may be an integrative centre for the expression of genetic effects on growth potential.

We observed that POMC and CART expression were higher in males compared with females in the AL fed groups. There has been some discrepancy in the literature regarding $P O M C$ mRNA expression after re-feeding with examples of both increased expression and no effect [48, 49]. It appears that studies of males did see a difference between restricted and AL fed groups but studies of females did not, which matches the results observed in this study $[49,50]$. Although it should be noted that these sex differences in anorectic neuropeptide expression were not observed in our repeat study, the experiment sample size was based on a power analysis for AGRP expression changes and the statistical power may not have been sufficient to detect changes in the expression of the POMC and CART genes. 
In birds, it has been observed that male and female somatic cells in gynandromorphs respond in different ways to a common steroidal milieu with male and female characteristics developing according to the proportion of the respective male and female cells in a tissue [51-53]. This is known as 'cell autonomous sexual identity' (CASI) which suggests that cells appear to 'know' their sex and develop according to the genetic sex. This CASI theory could be used to explain the sexually dimorphic phenotypes observed in birds, but is still controversial as the evidence from gynandromorphs is mainly correlational. Yet, there is support for the CASI theory because the transplantation of cells from a host prior to gonad differentiation will go onto develop a somatic cell fate but maintain the differentiated gene expression of the sex of the donor tissue [51]. However, there is still a body of evidence that some of these sex chromosomedetermined phenotypes are also influenced by gonadal hormones; one of the clearest examples being the chicken's comb and wattle [54, 55]. In terms of growth in chickens, research has only been able to investigate the influence of gonadal hormones and observed that blocking aromatase with Fadrozole in the embryo, so effectively sex reversing females so they experience male hormone milieu but are genetically female, increased growth by day 42 post hatch and apparently attenuated the difference between males and females [56]. Also, body weight gain was inhibited by the application of androgens in male, female or castrated chickens [57]. In mice which have been engineered to have male $(\mathrm{XY})$ or female (XX) chromosome complements but develop within each genotype to have male or female gonads, there are examples of genetic effects on body weightrelated traits. Mice carrying female sex chromosomes, irrespective of gonadal type, demonstrated greater food intake during daylight hours and double the amount of adipose tissue [58]. Evidence of genes responsible for the genetic effect on gene expression and potential sexlinked genes responsible for the trans effects on those genes were identified [58].

It is clear that there are many interesting questions surrounding what, sex chromosomes or gonadal hormones, determines sex differences in the expression of the arcuate nucleus neuropeptide genes and potentially growth and body weight. Further research will be needed to explore these questions.

The addition of the bulking agent, ispaghula husk, had no significant effect on the expression of the orexigenic peptides in the basal hypothalamus compared to normal feed restriction; both groups had significantly higher $A G R P$ and NPY expression than the AL group released from the restricted diet. This strongly suggests that the bulking agent supplies no mechanosensory signals from the gut to the brain to reduce expression of $N P Y$ and
AGRP in the orexigenic neurons. These results are in line with other studies in which it was observed that the level of crop fill, used as a marker of recent food ingestion, was not associated with hypothalamic expression of AGRP, $P O M C$ or $N P Y$ [59]. Ispaghula husk was added to the diet as a non-nutritive bulking agent, and our visual observation that it appeared to physically fill the crop and gut suggested that it acted in this manner. Its effects are likely to be comparable to other diet bulking agents such as oat hulls where improvements in behaviour are observed whilst still limiting growth rate [60]. The AL group had a significantly increased body weight compared to the FR and $\mathrm{IH}$ group. This increase is unlikely to be entirely attributable to crop content weight as the $\mathrm{IH}$ group also had significantly higher values, but there was no difference in their body weights compared with the FR group. This suggested that the $\mathrm{IH}$ diet was nutritionally limited as expected. Further support for this is the absence of significant differences in expected direction (i.e. increasing in size) in the majority of organ weights between the FR and $\mathrm{IH}$ groups compared to the significantly increased values in the AL group. For example, after 2.5 days, the liver was more than double the weight in the AL group compared to the FR and IH groups (see Table 1 for other organ weights). These points together prove that the addition of ispaghula husk provided bulk but little or no nutrients; indeed, it was observed the IH group took most of the daylight period to eat their ration whereas the FR group food was eaten within the first $10 \mathrm{~min}$, suggesting the bulking effect caused gut fill and slowed down food intake and passage. This is largely the mechanism put forward for its benefit in treating gastrointestinal mobility issues in humans [61-63].

In mammals, the vagal afferents are suggested to relay mechanoreceptive stimuli to the nucleus tractus solitarius in the hind brain and this signalling can be modified by the action of classic satiety peptides [64]. These afferents and the pathways they activate in the brain represent an important target for future studies to understand the control of food intake in birds. The role of mechanoreceptors in the gut and the afferent pathways to the brain may be more important in birds, but relatively little is known of their methods of action in birds at present $[65,66]$. From what we have observed in these experiments, IH provided bulk and slowed food intake but resulted in no alteration in hypothalamic gene expression compared with restricted birds. It seems likely that the inhibitory effect of gut fill on food intake is achieved by a mechanism independent of an action on AGRP/NPY and POMC/CART neurons. This may be the case only in broiler breeders; as was discussed above, injection of AGRP had no effect on food intake but did increase it in layer chicks [19]. It may be that in broilers in particular, AGRP neuronal activity may actually relate to the state of energy balance and a bird's growth 
potential as much as to predicting actual intake of food, particularly when there is no food choice as we have seen in a number of paradigms including the present study [9].

\section{Conclusion}

To conclude, we observed clear sex differences in the expression of central food regulatory genes, which exist in genetically distinct lines of chickens and are independent of feeding status. The higher level of AGRP mRNA in males adds further evidence to the idea that the level of its expression in the chicken hypothalamus is an indicator of a bird's growth potential. Although research into understanding how AGRP may determine growth is just at its beginning, the role of AGRP in modulating the central melanocortin system is a good candidate mechanism for determining long-term growth as well as short-term food intake. Although IH bulked out the diet and spread food intake over a longer period, there were no changes in arcuate nucleus neuropeptide gene expression suggesting that mechanosensory signals do not impact upon the expression of satiety signals in the brain. However, the use of bulking agents to increase time spent showing feeding behaviour without metabolic satiation but whilst restricting growth seems to have welfare advantages from previous studies [30-34]. The mechanism underlying the apparent welfare improvement currently remains unknown but may involve neural signals from the gut to the brain via vagal afferents.

\section{Additional file}

Additional file 1: Figure S1. Average weekly body weights for male and female chickens in a genetically distinct line. The average weekly body weights for male $(n=57)$ and female $(n=52)$ from broiler layer hybrid line fed on an ad libitum diet. $P$ values are from a repeated measure ANOVA with different labels $\left({ }^{*}=p<0.05,{ }^{* *} p<0.01\right.$, $\left.{ }^{* *} p<0.001\right)$ indicating differences between means from post hoc tests. (PDF $361 \mathrm{~kb}$ )

\section{Abbreviations}

ACTH: Adrenocorticotrophic hormone; AGRP: Agouti-related peptide; AL: Ad libitum diet; ANOVA: Analysis of variance; CART: Cocaine- and amphetamineregulated transcript; CASI: Cell autonomous sexual identity;

CCKAR: Cholecystokinin A receptor; FR: Commercial restricted diet; ICV: Intracerebroventricular; $\mathrm{IH}$ : Commercial restricted diet plus 15\% W/W ispaghula husk; MC4R(s): Melanocortin 4 receptor(s); NPY: Neuropeptide Y; PCR: Polymerase chain reaction; SEM: Standard error of the mean; aMSH: Amelanocyte-stimulating hormone

\section{Acknowledgements}

We would like to express our gratitude to the staff of the National Avian Research Facility (NARF) in Edinburgh for their skilful animal husbandry and assistance in other practicalities. We would like to thank the Editor and Reviewers for their comments and suggestions which have helped strengthen the work carried out.

\section{Funding}

Animal work was funded by BBSRC grant 'Investigating how the type and quantity of food affect foraging behaviour and the neural circuits controlling feeding in broiler breeder chickens' (BB/L000199/1) and the Roslin Institute strategic programme grant (BB/J004316/1 and BBS/E/D/30002276). SRUC and Biomathematics \& Statistics Scotland are supported by the Rural and
Environmental Science and Analytical Services Division of the Scottish Government.

\section{Availability of data and materials}

The datasets generated and analysed during the current study are available in the University of Edinburgh data share repository https://doi.org/10.7488/ds/2293.

\section{Authors' contributions}

SB analysed the data for experiment section "Sex and diet effect" along with the advice on the experimental design. AR provided substantial contribution to the design and acquisition of data for experiment section "Genetically distinct line". NM provided substantial contribution to the acquisition of data for experiment section "Sex and diet effect". PWW was significantly involved in the design and acquisition of data from all experiments. ICD was a major contributor to the designs of the experiment, data collection, data interpretation and writing the manuscript. TB and RB were considerably involved in the experiment designs, with TB providing input on writing the manuscript. SDC was extensively involved in the experimental design, data collection, analysis and interpretation alongside being a major contributor to writing of the manuscript. All authors read and approved the final manuscript.

\section{Ethics approval}

All animal experiments were performed under UK Home Office Project Licence 70/7909, and birds were humanely killed as specified in Schedule 1 of the UK Animals (Scientific Procedures) Act 1986.

\section{Competing interests}

The authors declare that they have no competing interests.

\section{Publisher's Note}

Springer Nature remains neutral with regard to jurisdictional claims in published maps and institutional affiliations.

\section{Author details}

${ }^{1}$ The Roslin Institute and Royal (Dick) School of Veterinary Studies, University of Edinburgh, Easter Bush, Midlothian, Edinburgh EH25 9RG, Scotland, UK. ${ }^{2}$ Bioinformatics and Statistics Scotland, Edinburgh, Scotland, UK. ${ }^{3}$ Scotland's Rural College, Edinburgh, Scotland, UK. ${ }^{4}$ School of Natural and Environmental Sciences, Newcastle University, Newcastle upon Tyne, England, UK.

Received: 23 January 2018 Accepted: 7 May 2018

Published online: 29 May 2018

\section{References}

1. Berns CM. The evolution of sexual dimorphism: understanding mechanisms of sexual shape differences. In: Moriyama PH, editor. Sexual dimorphism. Rijeka: InTech; 2013. p. 1-16.

2. Amadon D. The significance of sexual differences in size among birds. Proc Am Philos Soc. 1959;103:531-6.

3. Ralls K. Mammals in which females are larger than males. Q Rev Biol. 1976; 51:245-76.

4. Andersson $M$, Norberg RÅ. Evolution of reversed sexual size dimorphism and role partitioning among predatory birds, with a size scaling of flight performance. Biol J Linn Soc. 1981;15:105-30.

5. Sears R, Perrin WF. Blue Whale: Balaenoptera musculus. In: Encyclopedia of marine mammals. 2nd ed. London: Academic Press; 2009. p. 120-4.

6. Frank LG. Social organization of the spotted hyaena Crocuta crocuta. II. Dominance and reproduction. Anim Behav, 1986:34:1510-27.

7. Loganathan N, Belsham DD. Nutrient-sensing mechanisms in hypothalamic cell models: neuropeptide regulation and neuroinflammation in male- and female-derived cell lines. American journal of physiology Regulatory, integrative and comparative. Physiology. 2016;311:R217-21.

8. Dunn IC, Wilson PW, D'Eath RB, Boswell T. Hypothalamic agouti-related peptide mRNA is elevated during natural and stress-induced anorexia. J Neuroendocrinol. 2015:27:681-91.

9. Dunn IC, Meddle SL, Wilson PW, Wardle C, Law AS, Bishop V, Hindar C, Robertson GW, Burt DW, Ellison SJL, et al. Decreased expression of the satiety signal receptor CCKAR is responsible for increased growth and body weight during the domestication of chickens. Am J Physiol Endocrinol Metab. 2013;304:E909-21. 
10. Dunn IC, Wilson PW, Smulders TV, Sandilands V, D'Eath RB, Boswell T. Hypothalamic agouti-related protein expression is affected by both acute and chronic experience of food restriction and re-feeding in chickens. J Neuroendocrinol. 2013;25:920-8.

11. Maniatis G, Demiris N, Kranis A, Banos G, Kominakis A. Genetic analysis of sexual dimorphism of body weight in broilers. J Appl Genet. 2013;54:61-70.

12. Remes V, Szekely T. Domestic chickens defy Rensch's rule: sexual size dimorphism in chicken breeds. J Evol Biol. 2010;23:2754-9.

13. Management Guide, Lohmann Brown, Lohmann LSL parent stock [http://www Itz.de/de-wAssets/docs/management-guides/en/PS/LTZ_MG_LB-LSL-PS_EN.pdf].

14. Goto N, Ishikawa A, Tsudzuki M. Growth curve analysis for a QTL resource family F-2 intercross of the oh-shamo and white leghorn breeds of chickens. J Anim Vet Adv. 2011;10:3207-11.

15. Boswell T, Dunn IC. Regulation of the avian central melanocortin system and the role of leptin. Gen Comp Endocrinol. 2015;221:278-83.

16. Boswell T, Dunn IC. Regulation of agouti-related protein and proopiomelanocortin gene expression in the avian arcuate nucleus. Front Endocrinol. 2017;8:75.

17. Hahn TM, Breininger JF, Baskin DG, Schwartz MW. Coexpression of AGRP and NPY in fasting-activated hypothalamic neurons. Nat Neurosci. 1998;1:271-2.

18. Ling MK, Hotta E, Kilianova Z, Haitina T, Ringholm A, Johansson L, GalloPayet N, Takeuchi S, Schioth HB. The melanocortin receptor subtypes in chicken have high preference to ACTH-derived peptides. Br J Pharmacol. 2004; 143:626-37.

19. Tachibana T, Sugahara K, Ohgushi A, Ando R, Kawakami S-I, Yoshimatsu T, Furuse M. Intracerebroventricular injection of agouti-related protein attenuates the anorexigenic effect of alpha-melanocyte stimulating hormone in neonatal chicks. Neurosci Lett. 2001;305:131-4.

20. Food and Agricultural Orgnization of the United Nations: FAO World Food Outlook 2014. 2014 http://www.fao.org/ag/againfo/themes/en/meat/ background.html. Accessed Nov 2014

21. Havenstein GB, Ferket PR, Qureshi MA. Growth, livability, and feed conversion of 1957 versus 2001 broilers when fed representative 1957 and 2001 broiler diets. Poult Sci. 2003;82:1500-8.

22. De Jong IC, Guémené D. Major welfare issues in broiler breeders. World's Poultry Sci J. 2011;67:73-82.

23. Mench JA. Broiler breeders: feed restriction and welfare. World's Poultry Sci J. 2002;58:23-9.

24. Hocking PM. Welfare of broiler breeder and layer females subjected to food and water control during rearing: quantifying the degree of restriction. $\mathrm{Br}$ Poult Sci. 1993;34:53-64.

25. Heck A, Onagbesan O, Tona K, Metayer S, Putterflam J, Jego Y, Trevidy JJ, Decuypere E, Williams J, Picard M, Bruggeman V. Effects of ad libitum feeding on performance of different strains of broiler breeders. Br Poult Sci. 2004:45:695-703.

26. Health EPOA, Welfare. Scientific opinion on welfare aspects of the management and housing of the grand-parent and parent stocks raised and kept for breeding purposes. EFSA J. 2010;8:1667. n/a

27. Dixon LM, Brocklehurst S, Sandilands V, Bateson M, Tolkamp BJ, D'Eath RB. Measuring motivation for appetitive behaviour: food-restricted broiler breeder chickens cross a water barrier to forage in an area of wood shavings without food. PLoS One. 2014;9:e102322.

28. Decuypere E, Hocking PM, Tona K, Onagbesan O, Bruggeman V, Jones EKM, Cassy S, Rideau N, Metayer S, Jego Y, et al. Broiler breeder paradox: a project report. World's Poultry Sci J. 2006;62:443-53.

29. Savory CJ, Maros K, Rutter SM. Assessment of hunger in growing broiler breeders in relation to a commercial restricted feeding programme. Anim Welf. 1993;2:131-52

30. Sandilands V, Tolkamp BJ, Savory CJ, Kyriazakis I. Behaviour and welfare of broiler breeders fed qualitatively restricted diets during rearing: are there viable alternatives to quantitative restriction? Appl Anim Behav Sci. 2006;96:53-67.

31. Hocking PM, Bernard R, Robertson GW. Effects of low dietary protein and different allocations of food during rearing and restricted feeding after peak rate of lay on egg production, fertility and hatchability in female broiler breeders. Br Poult Sci. 2002;43:94-103.

32. De Jong IC, Enting $H$, van Voorst $A$, Blokhuis HJ. Do low-density diets improve broiler breeder welfare during rearing and laying? Poult Sci. 2005;84:194-203.

33. Nielsen BL, Thodberg K, Malmkvist J, Steenfeldt S. Proportion of insoluble fibre in the diet affects behaviour and hunger in broiler breeders growing at similar rates. Animal. 2011;5:1247-58.
34. Tolkamp BJ, Sandilands V, Kyriazakis I. Effects of qualitative feed restriction during rearing on the performance of broiler breeders during rearing and lay. Poult Sci. 2005;84:1286-93.

35. Hara H, Saito Y, Nagata M, Tsuji M, Yamamoto K, Kiriyama S. Artificial fiber complexes composed of cellulose and guar gum or psyllium may be better sources of soluble fiber for rats than comparable fiber mixtures. J Nutr. 1994;124:1238-47.

36. Brum JM, Gibb RD, Peters JC, Mattes RD. Satiety effects of psyllium in healthy volunteers. Appetite. 2016;105:27-36.

37. Rigaud D, Paycha F, Meulemans A, Merrouche M, Mignon M. Effect of psyllium on gastric emptying, hunger feeling and food intake in normal volunteers: a double blind study. Eur J Clin Nutr. 1998;52:239-45.

38. Podisi BK, Knott SA, Dunn IC, Law AS, Burt DW, Hocking PM. Overlap of quantitative trait loci for early growth rate, and for body weight and age at onset of sexual maturity in chickens. Reproduction. 2011:141:381-9.

39. Lal P, Sharp PJ, Dunn IC, Talbot RT. Absence of an effect of naloxone, an opioid antagonist, on luteinizing hormone release in vivo and luteinizing hormone-releasing hormone I release in vitro in intact, castrated, and food restricted cockerels. Gen Comp Endocrinol. 1990;77:239-45.

40. Clinton M, Haines L, Belloir B, McBride D. Sexing chick embryos: a rapid and simple protocol. Br Poult Sci. 2001:42:134-8.

41. Wang L, Goebel-Stengel M, Yuan PQ, Stengel A, Tache Y. Corticotropinreleasing factor overexpression in mice abrogates sex differences in body weight, visceral fat, and food intake response to a fast and alters levels of feeding regulatory hormones. Biol Sex Differ. 2017;8:2.

42. Burke LK, Doslikova B, D'Agostino G, Greenwald-Yarnell M, Georgescu T, Chianese R, Martinez de Morentin PB, Ogunnowo-Bada E, Cansell C, Valencia-Torres $L$, et al. Sex difference in physical activity, energy expenditure and obesity driven by a subpopulation of hypothalamic POMC neurons. Mol Metab. 2016;5:245-52.

43. Guillot R, Cortes R, Navarro S, Mischitelli M, Garcia-Herranz V, Sanchez E, Cal L, Navarro JC, Miguez JM, Afanasyev S, et al. Behind melanocortin antagonist overexpression in the zebrafish brain: a behavioral and transcriptomic approach. Horm Behav. 2016;82:87-100.

44. Huszar D, Lynch CA, Fairchild-Huntress V, Dunmore JH, Fang Q, Berkemeier LR, Gu W, Kesterson RA, Boston BA, Cone RD, et al. Targeted disruption of the melanocortin-4 receptor results in obesity in mice. Cell. 1997;88:131-41.

45. Graham M, Shutter JR, Sarmiento U, Sarosi I, Stark KL. Overexpression of Agrt leads to obesity in transgenic mice. Nat Genet. 1997;17:273-4.

46. Zhang C, Forlano PM, Cone RD. AgRP and POMC neurons are hypophysiotropic and coordinately regulate multiple endocrine axes in a larval teleost. Cell Metab. 2012;15:256-64.

47. Zhang J, Li X, Zhou Y, Cui L, Li J, Wu C, Wan Y, Li J, Wang Y. The interaction of MC3R and MC4R with MRAP2, ACTH, alpha-MSH and AGRP in chickens. J Endocrinol. 2017;234:155-74.

48. Lei L, Lixian Z. Effect of $24 \mathrm{~h}$ fasting on gene expression of AMPK, appetite regulation peptides and lipometabolism related factors in the hypothalamus of broiler chicks. Asian-Australas J Anim Sci. 2012;25:1300-8.

49. Song Z, Liu L, Yue Y, Jiao H, Lin H, Sheikhahmadi A, Everaert N, Decuypere E, Buyse J. Fasting alters protein expression of AMP-activated protein kinase in the hypothalamus of broiler chicks (Gallus gallus domesticus). Gen Comp Endocrinol. 2012;178:546-55.

50. Yuan L, Ni Y, Barth S, Wang Y, Grossmann R, Zhao R. Layer and broiler chicks exhibit similar hypothalamic expression of orexigenic neuropeptides but distinct expression of genes related to energy homeostasis and obesity. Brain Res. 2009;1273:18-28.

51. Zhao D, McBride D, Nandi S, McQueen HA, McGrew MJ, Hocking PM, Lewis PD, Sang HM, Clinton M. Somatic sex identity is cell autonomous in the chicken. Nature. 2010;464:237-U115.

52. Chue J, Smith CA. Sex determination and sexual differentiation in the avian model. FEBS J. 2011;278:1027-34.

53. Agate RJ, Grisham W, Wade J, Mann S, Wingfield J, Schanen C, Palotie A, Arnold AP. Neural, not gonadal, origin of brain sex differences in a gynandromorphic finch. Proc Natl Acad Sci. 2003;100:4873-8.

54. Arnold AP, Chen X, Link JC, Itoh Y, Reue K. Cell-autonomous sex determination outside of the gonad. Dev Dyn. 2013;242:371-9.

55. Arnold AP, Itoh Y. Factors causing sex differences in birds. Avian Biol Res. 2011;4 https://doi.org/10.3184/175815511X13070045977959.

56. Mohammadrezaei M, Toghyani M, Gheisari A, Eghbalsaied S. Synergistic effect of fadrozole and insulin-like growth factor-I on female-to-male sex reversal and body weight of broiler chicks. PLoS One. 2014;9:e103570. 
57. Fennell MJ, Scanes CG. Inhibition of growth in chickens by testosterone, 5alpha-dihydrotestosterone, and 19-nortestosterone. Poult Sci. 1992;71:357-66.

58. Chen XQ, McClusky R, Chen J, Beaven SW, Tontonoz P, Arnold AP, Reue K. The number of $X$ chromosomes causes sex differences in adiposity in mice. PLoS Genet. 2012;8:e1002709.

59. Lees JJ, Lindholm C, Batakis P, Busscher M, Altimiras J. The physiological and neuroendocrine correlates of hunger in the Red Junglefowl (Gallus gallus). Sci Rep. 2017;7:17984.

60. Sandilands V, Tolkamp BJ, Kyriazakis I. Behaviour of food restricted broilers during rearing and lay-effects of an alternative feeding method. Physiol Behav. 2005;85:115-23.

61. Perez-Miranda M, Gomez-Cedenilla A, Leon-Colombo T, Pajares J, MateJimenez J. Effect of fiber supplements on internal bleeding hemorrhoids. Hepato-Gastroenterology. 1996;43:1504-7.

62. Davies GJ, Dettmar PW, Hoare RC. The influence of ispaghula husk on bowel habit. J R Soc Promot Heal. 1998;1 18:267-71.

63. McRorie JW Jr, McKeown NM. Understanding the physics of functional fibers in the gastrointestinal tract: an evidence-based approach to resolving enduring misconceptions about insoluble and soluble fiber. J Acad Nutr Diet. 2017;117:251-64.

64. Grabauskas G, Owyang C. Plasticity of vagal afferent signaling in the gut. Medicina Lithuania. 2017;53:73-84.

65. Tachibana T, Hiramatsu K, Furuse M, Hasegawa S, Yoshizawa F, Sugahara K. Distribution of proglucagon mRNA and GLP-1 in the brainstem of chicks. Comp Biochem Physiol A Mol Integr Physiol. 2005;140:203-7.

66. Tashani OA, Leek BF. Mechanoreceptors in the crop of the domestic-fowl. Poult Sci. 1994;73:744-8.

\section{Ready to submit your research? Choose BMC and benefit from:}

- fast, convenient online submission

- thorough peer review by experienced researchers in your field

- rapid publication on acceptance

- support for research data, including large and complex data types

- gold Open Access which fosters wider collaboration and increased citations

- maximum visibility for your research: over $100 \mathrm{M}$ website views per year

At BMC, research is always in progress.

Learn more biomedcentral.com/submissions 